\title{
Dinitrogen and methane gas production during the anaerobic/anoxic decomposition of animal manure
}

\author{
Lowry A. Harper • Kim H. Weaver • \\ Alex De Visscher
}

Received: 14 February 2014/ Accepted: 10 July 2014/Published online: 31 July 2014

(C) The Author(s) 2014. This article is published with open access at Springerlink.com

\begin{abstract}
Trace-gas emissions from animal feeding operations (AFOs) can contribute to air quality and global change gases. Previous and current estimated gas emissions from AFOs vary widely and many do not consider all forms of carbon (C) and nitrogen (N) emissions. Studies have found that as methanogenesis in the lagoons increased, conversion of ammonium $\left(\mathrm{NH}_{4}{ }^{+}\right)$to dinitrogen $\left(\mathrm{N}_{2}\right)$ also increased. The purpose of this research was to measure $\mathrm{N}_{2}$ and $\mathrm{CH}_{4}$ emissions from swine AFOs in three locations of the U.S. and to evaluate the possible universal relationship between lagoon methanogenesis and the conversion of $\mathrm{NH}_{4}{ }^{+}$to $\mathrm{N}_{2}$ gas. This relationship was tested by measuring $\mathrm{N}_{2}$ and $\mathrm{CH}_{4}$ emissions in two climates at 22 different farms. Methanogenesis was correlated with $\mathrm{NH}_{4}{ }^{+}$-to- $\mathrm{N}_{2}$ conversion by a nearconstant $\mathrm{N}_{2}$ to $\mathrm{CH}_{4}$ emissions ratio of 0.20 , regardless
\end{abstract}

L. A. Harper $(\varangle)$

Lowry A. Harper Consulting Co.,

P.O. Box 772, Watkinsville, GA 30677, USA

e-mail: lowry.harper.pe@gmail.com

K. H. Weaver

Department of Physical Science, Southern Utah

University, 351 W. Center, Cedar City, UT 84720, USA

A. De Visscher

Department of Chemical and Petroleum Engineering, and Centre for Environmental Engineering Research and Education (CEERE), University Calgary, Calgary,

AB T2N 1N4, Canada of $\mathrm{C}$ loading and climatic effects. The process is shown to be thermodynamically favored when there is competition between $\mathrm{NH}_{4}^{+}$oxidizing reactions. Under methanogenic conditions (redox potentials of methanogenesis) $\mathrm{N}_{2}$ production is favorable and nitrification/denitrification is not. Thus, $\mathrm{N}_{2}$ production is stimulated in methanogenic conditions. Evaluation of $\mathrm{NH}_{3}$ gas emissions from AFOs must consider other $\mathrm{N}$ emissions than $\mathrm{NH}_{3}$. Finally, a statistical model was developed to estimate methane and $\mathrm{N}_{2}$ emissions $\left(\mathrm{kg} \mathrm{gas} \mathrm{ha}^{-1}\right)$ given feed input per lagoon surface area $\left(\mathrm{kg}\right.$ feed $\mathrm{ha}^{-1}$ ) and local air temperature. Further studies are needed to investigate the mechanisms involved in manure processing and isolate the favorable mechanisms into engineering improved manure processing.

Keywords Ammonium - Methane ·

Methanogenesis · Thermodynamics · Lagoon ·

Dinitrogen

\section{Introduction}

Ammonia $\left(\mathrm{NH}_{3}\right)$ is a significant air pollutant, especially in combination with acid gas production from fossil fuel combustion, because the resulting acidbase reaction potentially leads to an air quality problem in the form of haze and respirable particulate matter (PM). The link between PM and increased 
mortality is well established (Pope et al. 2002; Cohen et al. 2005). Ammonia emissions' estimates from swine manure treatment lagoons, as a percent of feed nitrogen $(\mathrm{N})$ input, have been reported to vary from 36 to $71 \%$ (Doorn et al. 2002a; Hatfield et al. 1993; USEPA. 2004). From a systems' analysis approach using the USEPA National Emissions Inventory (USEPA, 2004), the addition of all $\mathrm{NH}_{3}$ emissions' components, such as from housing (22\%), lagoons (43\%), field application of manure (23\%), N leaving as animal protein (30\%, from host data), suggest that more than $100 \%$ of the $\mathrm{N}$ entering the farm system is leaving the farm as $\mathrm{NH}_{3}$ volatilization plus animal product. Recent studies in North Carolina (NC) (Harper et al. 2004b), the Georgia Coastal Plains (GA) (Harper and Sharpe 1998; Harper et al. 2000), and the Central Great Basin (CGB) (Harper et al. 2010; Weaver et al. 2012) regions have shown that swine lagoons emit significantly less $\mathrm{NH}_{3}$ than previously and currently thought. Much of the $\mathrm{N}$ estimated as $\mathrm{NH}_{3}$ gas emissions has been found to be converted to dinitrogen gas $\left(\mathrm{N}_{2}\right)$ (Harper et al. 2000, 2004b; Weaver et al. 2012), representing an even larger discrepancy for the $\mathrm{N}$ balance of farm systems suggested by the USEPA. This aspect of dinitrogen emissions, not considered in most of the estimates of $\mathrm{NH}_{3}$ emissions from animal feeding operations (AFOs), highlights the fact that the $\mathrm{N}$ cycle in lagoons is not fully understood. Benign $\mathrm{N}_{2}$ emission from lagoons is a pathway of $\mathrm{N}$ emissions is that is significant and must be considered in the total $\mathrm{N}$ balance of AFOs. When the National Emissions Inventory (USEPA 2004) $\mathrm{NH}_{3}$ emissions values are combined with published (measured) $\mathrm{N}_{2}$ emissions (Harper et al. 2000, 2004a, b; Weaver et al. 2012), in many cases more $\mathrm{N}$ as $\mathrm{NH}_{3}$ plus $\mathrm{N}_{2}$ is emitted than is excreted by the animals, suggesting the need to reevaluate emissions' estimates.

Many of the current $\mathrm{NH}_{3}$ emissions' estimates are based upon chamber measurements. A number of studies using dynamic chamber measurements (Aneja et al. 2000; Blunden and Aneja 2008) have led to higher emission estimates than found by micrometeorological measurements (Harper and Sharpe 1998; Harper et al. 2000, 2004b, 2010). Doorn et al. (2002b) pointed out that studies with dynamic chambers led to emission factors 2.3 times higher than studies with micrometeorological techniques, while others (Shah et al. 2006; Rochette et al. 1992; Harper 2005; Harper et al. 2010;
2011 ) stated that chamber techniques are not even suitable for developing emission factors as they create conditions at the water surface that overestimate $\mathrm{NH}_{3}$ emissions. Based on all of the evidence (Harper et al. 2000, 2004b; Weaver et al. 2012) and discussions regarding the physical chemistry of highly anaerobic systems (van Clemput 1972, 1997), it seems very plausible that $\mathrm{NH}_{3}$ emissions from lagoons are lower than indicated by current emission factors and a significant fraction of $\mathrm{N}$ is emitted as $\mathrm{N}_{2}$.

There are complex interactions between carbon (C) and $\mathrm{N}$ compounds during manure processing by microbial and chemical processes. While little emissions' research for methane $\left(\mathrm{CH}_{4}\right)$ and carbon dioxide $\left(\mathrm{CO}_{2}\right)$ has been accomplished (Sharpe et al. 2001; DeSutter and Ham 2005) in AFOs, Harper et al. (2000; Table 1;2010) found interesting correlations between emissions of $\mathrm{NH}_{3}, \mathrm{CH}_{4}$, nitrous oxide $\left(\mathrm{N}_{2} \mathrm{O}\right)$, and $\mathrm{CO}_{2}$ from manure-processing lagoons. These and other studies (Harper et al. 2010) show that manure management aimed at reducing the emissions of one gas could have the undesired consequence of increasing emissions of other gases. In these studies, manure lagoons with a high rate of methanogenesis also converted significant amounts of ammonium $\left(\mathrm{NH}_{4}{ }^{+}\right)$ to benign $\mathrm{N}_{2}$ gas with little or no $\mathrm{N}_{2} \mathrm{O}$ produced [in the lagoons with the highest rate of methanogenesis, atmospheric $\mathrm{N}_{2} \mathrm{O}$ was actually absorbed by the lagoon (Harper et al. 2000)]; however, when methanogenesis decreased, smaller emissions of $\mathrm{N}_{2}$ occurred and higher rates of $\mathrm{N}_{2} \mathrm{O}$ were produced. Harper et al. (2010) also showed that removing organic material from swine production farms for biogas production reduced $\mathrm{CH}_{4}$ emissions by $47 \%$ (the reduction resulted in a $44 \%$ decrease in radiative forcing gases) from the biogas farms while increasing $\mathrm{NH}_{3}$ emissions from the biogas farms by $46 \%$, a substantial increase in air-quality emissions. Weaver et al. (2012) also showed similar results. The above studies suggest there is a relationship between the amount of methanogenesis and conversion of $\mathrm{NH}_{4}^{+}$to $\mathrm{N}_{2}$ gas in manure-processing lagoons. Thus, the main purpose of this study was to measure biological gas emissions from six manure-processing lagoons within a threecounty area of eastern NC, a farm in GA, and in a large swine operation in the CGB (15 farms), and to evaluate the relationship between methanogenesis $\left(\mathrm{CH}_{4}\right.$ production) and conversion of organic and inorganic $\mathrm{N}$ to $\mathrm{N}_{2}$ gas $\left(\mathrm{N}_{2}\right.$ production). 


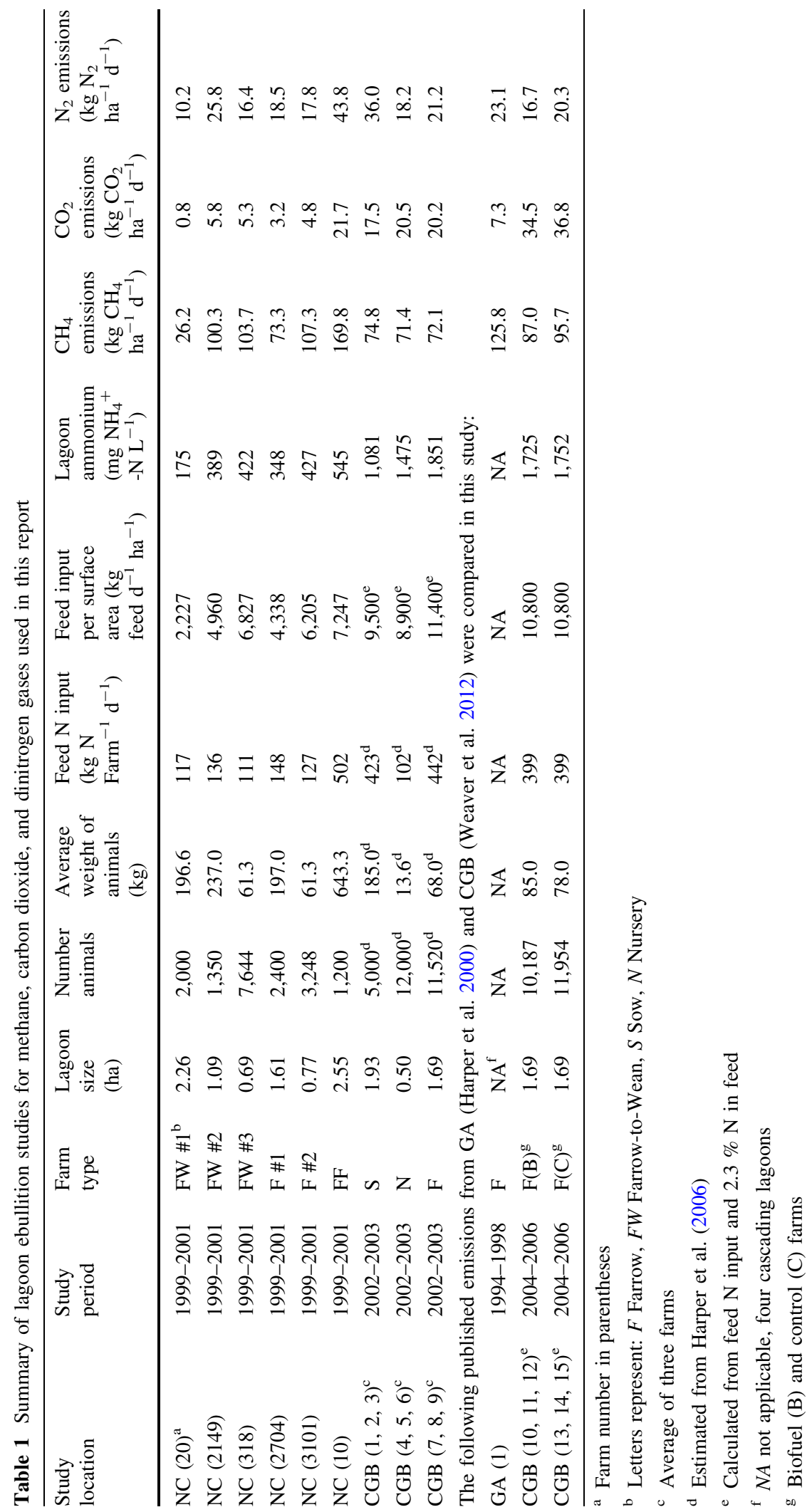




\section{Materials and methods}

In the 22 swine lagoons studied from all regions, undecomposed organic material (manure) from animal production houses is pumped to lagoons where the organic materials settle to the bottom forming a layer of semi-solid organic material which is anaerobically decomposed producing gas. Gas bubbles emitted from the sludge layer in each of the lagoons, were trapped in six collectors (Fig. 1) randomly located within each of six areas of the lagoon. These gas collectors do not interfere with the emission process, as with $\mathrm{NH}_{3}$ chambers (Harper, 2005). On a short-term basis $(<$ $\sim 2$ weeks), ebullition gases, the result of biological and thermodynamic processes, are emitted from the lagoon bottom and are not affected by climatic events at the lagoon surface; however, $\mathrm{NH}_{3}$ emissions are highly influenced by the physical processes of water surface turbulence and temperature. The collectors were made of $20-\mathrm{L}$, open-bottom carboys $(0.275 \mathrm{~m}$ diameter) with flotation collars at the top of the carboys (Fig. 1) and tethered to the lagoon bottom to collect the mass-flow gases (bubbles) before they reached the water-air interface. All air was removed from the collectors at placement. Water in the collectors was displaced by the ebullition gases over time, visually measured on a graduated scale on the collector periodically to determine gas mass-flux. Gases were transferred from the collectors using sample lines flushed with the gases from the collectors and then subsequently attached to evacuated six-L SUMMA canisters. The SUMMA canister samples were then transported to a laboratory where gas samples were analyzed by gas chromatography (Harper et al. 2004b; Weaver et al. Weaver et al. 2012). No $\mathrm{N}_{2} \mathrm{O}$ was found in the collectors via GC. In other studies no $\mathrm{N}_{2} \mathrm{O}$ emissions were found from anaerobic lagoons using atmospheric transport techniques and tunable diode laser spectroscopy (Harper et al. 2000, 2004a, b). Samples of helium (He) injected into the collectors showed a sampling procedure error of about $1 \%$ due to atmospheric $\mathrm{N}_{2}$ contamination (see Harper et al. 2004b). Further, modeling studies showed the theoretical maximum contamination from the atmosphere would be $<5-10 \%$ (De Visscher and Harper 2005, unpublished data). Gas fluxes were determined by measuring the amount of gases collected divided by the time between measuring intervals (collection volumes were measured as ebullition necessitated, normally from two to three times per week in summer and weekly or bimonthly in winter) and then multiplying the emissions by the measured concentrations of each gas. This sampling protocol has been used extensively and further description of the measurement technique may be found in Harper et al. (2000, 2004b) and Weaver et al. (2012).

A summary of all farms in this study is included in Table 1. Fifteen farms of four different types in the CGB were sampled during 2002-2006: two sets (2002-2003 and 2004-2006) of three each F farms; another set of three $\mathrm{F}$ farms with organic matter removed for biogas production (2004-2006); one set of three each of nursery (N) farms (2002-2003) and sow (S) farms (2002-2003). Data from 2004 to 2006 are from an earlier published study (after Weaver et al. 2012). Six farms were sampled during 1999-2001 for $\mathrm{N}$ and $\mathrm{C}$ emissions in $\mathrm{NC}$ including three farrow-towean (FW), two finisher (F), and one farrow-to-finish (FF) farms. Data from an F farm in GA during the period of 1994-1998 were included (after Harper et al. 2000). Farm animal numbers ranged from 1,400 to 12,000 .

Farms were selected in three geographical areas: fifteen in the CGB, six in three NC counties, and one in $\mathrm{GA}$, to evaluate the effect of management on biogas emission rates (subject to host availability). The farm types included F, FW, and FF farms with input feed protein ranging from 13 to $17 \%$ (feed $\mathrm{N}$ from 2.1 to $2.7 \%$ ). Three sow farms in the CGB were selected for comparison to production farms. Feed input, feed analysis, animal numbers and weights, number of animals sold, and other management information were supplied by the host owners/managers where available. Lagoon temperature was measured $2.5 \mathrm{~cm}$ below the water surface and within the sludge layer with micro temperature-loggers [Onset Computer Corp, Bourne, ME (Note: commercial names are included for the benefit of the reader and do not imply endorsement by the authors or their host institutions)]. The lagoons typically never formed crusts on the surface and were well mixed as demonstrated by near uniform temperatures from the top to the top of the sludge layer in lagoons of the CGB study. Since it is not appropriate to calculate $\mathrm{NH}_{3}$ emissions from chamber systems (Harper 2005), lagoon $\mathrm{NH}_{3}$ emissions were calculated from $\mathrm{pH}, \mathrm{NH}_{4}{ }^{+}$measurements of effluent samples (collected in bottles at the surface of each lagoon), surface lagoon temperatures, and 
wind speeds measured at $1.5 \mathrm{~m}$ height (from a metereological station on site), and a lagoon $\mathrm{NH}_{3}$ emissions model by De Visscher et al. (2002). Housing $\mathrm{NH}_{3}$ emissions were estimated from a model developed by Harper et al. (2004a) for North Carolina swine farms.

Effluent and sludge layer samples collected were frozen immediately and shipped to a laboratory for analysis of $\mathrm{NH}_{4}{ }^{+}$, nitrate $\left(\mathrm{NO}_{3}{ }^{-}\right)$, nitrite $\left(\mathrm{NO}_{2}{ }^{-}\right)$, and $\mathrm{pH}$ (for a description of analysis procedures see Harper et al. 2000, 2006). All lagoons were sampled similarly on a monthly basis.

The precision of biogas emission measurement was evaluated using the absolute value of the coefficient of variation, or relative standard deviation (RSD), obtained by dividing the standard deviation by the mean. To evaluate precision of the individual carboy measurements, the daily carboy emissions of the six lagoon carboys were used to calculate the daily average for the lagoon along with its RSD. The daily RSDs of the lagoons were averaged to calculate the average daily RSD and standard deviation of the daily RSD. To evaluate the precision of the farm lagoon emissions, a similar procedure was followed. Individual farm lagoon emissions are the average of the six carboy measurements. As lagoon emissions from three identical farms were measured for each farm type, the average individual farm emissions per farm type could be determined as well as the standard deviation of the individual farm emissions to calculate daily, monthly and yearly RSDs for each farm type. The RSDs for each farm type were averaged and a standard deviation was subsequently determined for daily, monthly and yearly RSD of individual farm emissions.

\section{Results and discussion}

Precision of biogas emission measurements

Average annual gas emissions (total component and percent of total) increased as the amount of farm inputfeed per size-of-lagoon increased (i.e. increased manure $\mathrm{C}$ with respect to lagoon processing size). Biogas production varied substantially among the six collectors on each lagoon site. The RSD between collectors on a single lagoon, on a daily basis, was $48 \pm 13 \%$. While there was considerable variability between individual collector's measurements, the

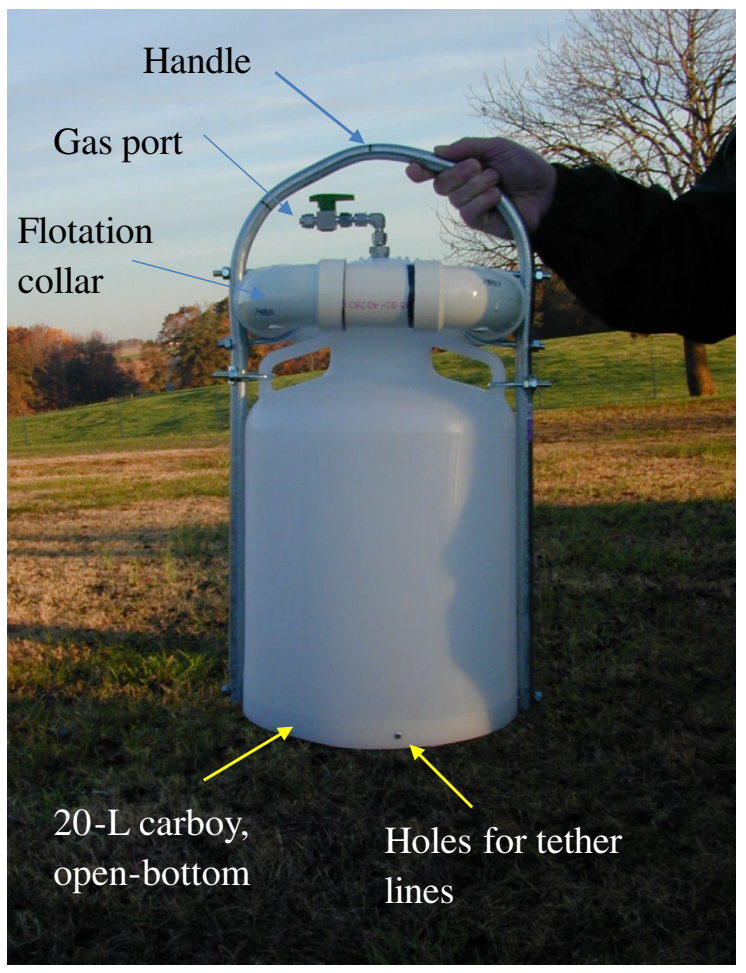

Fig. 1 Gas collectors constructed from open-bottom 20-L carboys. Graduations for evaluation of gas volumes located on the side of the carboy

variability of biogas emissions measurements was much less between lagoons when the six collectors were averaged. For example, the average RSDs of lagoon daily biogas emissions (average of six collectors) from lagoons of identical farms in the CGB were $23 \pm 2 \%$. The variability of measurements between identical farms decreased even further when compared on a monthly (average RSD $=14 \pm 6 \%$ ) or yearly basis $(8.8 \pm 6.0 \%)$. We interpret this to mean that the 6 collectors are adequate to determine representative emission measurements on a yearly basis. Individual gas emissions showed regression relationships vs. feed input $\left(\mathrm{R}^{2}\right)$ greater than 0.67 for total component emissions (Fig. 2a) and greater than 0.86 for percent of all component gas emissions versus feed input (Fig. 2b).

\section{Climate/temperature effects}

When comparing biogas production between farms, temperature effects in the lagoon sludge must be considered. Farms from the CGB were included to test 
the robustness of the trends in biogas production and their relationship to feed input and temperature. Each system monitored in the CGB was comprised of three identical farms allowing for quantification of the variance in the data. Average monthly $\mathrm{CH}_{4}$ production was directly related to sludge (where most of the processing occurs) temperature (Fig. 3a). On an annual basis, measured sludge temperatures were found to be within one degree $\left(0.8{ }^{\circ} \mathrm{C}\right.$ higher $)$ of the average annual air temperature at $1.5 \mathrm{~m}$ height (Harper and Weaver, unpublished data), and we suggest that air temperature can be used as a surrogate temperature for the sludge. When $\mathrm{CH}_{4}$ production was plotted versus average monthly air temperature (Fig. 3b), the gas production dependence upon monthly air temperature was almost as good as sludge temperature ( $\mathrm{R}^{2}$ values similar). Additionally, the dry climate of the CGB causes much higher evaporation rates and results in different management of swine lagoons.

\section{Feed input effects}

Data from the NC farms were used to test for the effects of feed input on biogas production. The NC data demonstrated that total biogas emissions ( $\mathrm{kg}$ gas $\mathrm{ha}^{-1} \mathrm{~d}^{-1}$ ) increased linearly (Fig. 2a) with daily feed input per lagoon size $\left(\mathrm{kg}\right.$ feed d $\left.\mathrm{d}^{-1} \mathrm{ha}^{-1}\right)\left(\mathrm{R}^{2}=0.67\right)$. Component gas emissions all increased linearly with feed input but $\mathrm{CH}_{4}$ had the largest increase with feed input per lagoon size $\left(\mathrm{R}^{2}=0.78\right)$. Carbon dioxide and $\mathrm{N}_{2}$ gas emissions also increased linearly but at smaller rates than $\mathrm{CH}_{4}$ (with correlations of $\mathrm{R}^{2}=0.76$ and 0.32 , respectively). Lower correlations for $\mathrm{N}_{2}$ gas can be partially explained by a change in composition of biogas with feed input (Fig. 2b) where $\mathrm{CH}_{4}$ and $\mathrm{CO}_{2}$ emissions, as the percentage of total gas production, increased and $\mathrm{N}_{2}$ emissions decreased with respect to increased daily feed input rates $\left(\mathrm{kg}_{\text {feed d }} \mathrm{hag}^{-1}\right)$. The $\mathrm{N}_{2}$ gas produced from the conversion of $\mathrm{NH}_{4}{ }^{+}$to $\mathrm{N}_{2}$, was not positively correlated with feed input (as was $\mathrm{CH}_{4}$ and $\mathrm{CO}_{2}$ ) since $\mathrm{N}_{2}$ is produced via a different mechanism than methanogenesis (Weaver et al. 2012).

Feed input values from the CGB could not be used to predict emissions (using the linear relationships determined in Fig. 2a) in other areas due to large differences in lagoon temperatures and to very different animal and manure management. In the CGB lagoons, no effluent was discharged from the lagoon system to maintain water levels (evaporation was sufficient); thus, organic matter was diminished only by anaerobic decomposition and all lagoon $\mathrm{N}$ was removed either via $\mathrm{NH}_{3}$ volatilization and/or conversion of $\mathrm{NH}_{4}^{+}$to $\mathrm{N}_{2}$ gas (Harper et al. 2000, 2004b; Weaver et al. 2012). Harper et al. (2000) found no $\mathrm{N}_{2} \mathrm{O}$ emissions from swine anaerobic processing lagoons (indeed, there was absorption of $\mathrm{N}_{2} \mathrm{O}$ from the atmosphere by the lagoon). Additionally, because the feed input ( $\mathrm{kg}$ feed $\mathrm{ha}^{-1} \mathrm{~d}^{-1}$ ) was similar between lagoons in CGB (Table 1), the relationship between feed input and emissions could not be tested in the CGB.

The relationship between $\mathrm{NH}_{4}{ }^{+}$concentration and gas emissions was evaluated in the NC lagoons. Similar to lagoon biogas emissions in a GA study (Harper et al. 2000), as $\mathrm{NH}_{4}{ }^{+}$concentration increased across the six NC lagoons, total and individual gas emissions increased. However, the increased emissions effect was due to an increase in manure availability resulting in more biological decomposition from more feed input (Fig. 2a). Additionally, $\mathrm{NH}_{4}{ }^{+}$concentrations also increased with more biological decomposition. Consequently, higher $\mathrm{NH}_{4}{ }^{+}$ concentrations and gas emissions are both correlated to feed input and not necessarily to each other.

Mechanisms for $\mathrm{N}_{2}$ production

When Harper et al. (2000) could not balance the feed $\mathrm{N}$ input and all forms of $\mathrm{N}$ output (including meat, lagoon $\mathrm{NH}_{3}$ volatilization, field application $\mathrm{NH}_{3}$ losses, field denitrification losses of $\mathrm{N}_{2}$ and $\mathrm{N}_{2} \mathrm{O}$ emissions, lagoon $\mathrm{N}_{2} \mathrm{O}$ emissions, etc.), they suggested the possibility that some of the $\mathrm{NH}_{4}{ }^{+}$may have been converted to $\mathrm{N}_{2}$ during manure-processing and that different reactions were involved, depending on the $\mathrm{N}$ form and concentration. With higher $\mathrm{NH}_{4}{ }^{+}$ concentration and biological activity (i.e. $\mathrm{CH}_{4}$ production) their studies suggested that the $\mathrm{N}_{2}$ production may have occurred via 'chemical denitrification' (Van Cleemput 1997). Thermodynamics and the Gibbs free energy of reaction for chemical denitrification (Van Cleemput 1972) suggest that spontaneous conversion of $\mathrm{NH}_{4}^{+}$to $\mathrm{N}_{2}$ may occur in animal manure lagoons (Harper et al. 2004b, Table 7). It is possible that there is some biological denitrification in the lagoons, but we think it is small since we measured little $\mathrm{NO}_{3}{ }^{-}$ $\left(<0.1 \mathrm{mg} \mathrm{NO}_{3}{ }^{-}-\mathrm{N} \mathrm{\textrm {L } ^ { - 1 }}\right)$. Furthermore, dissolved 

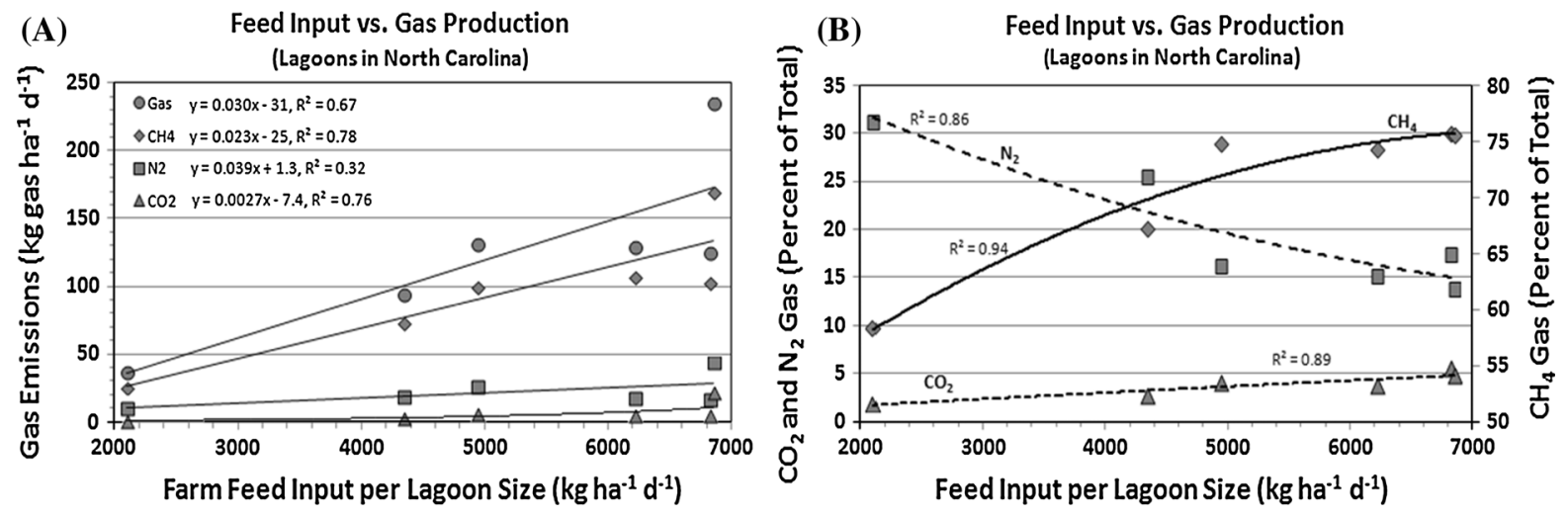

Fig. 2 Average annual lagoon methane, dinitrogen, and carbon dioxide emissions as emissions per unit area of lagoon surface (a) and percent of total gas emissions (b) with respect to feed input per lagoon size in North Carolina

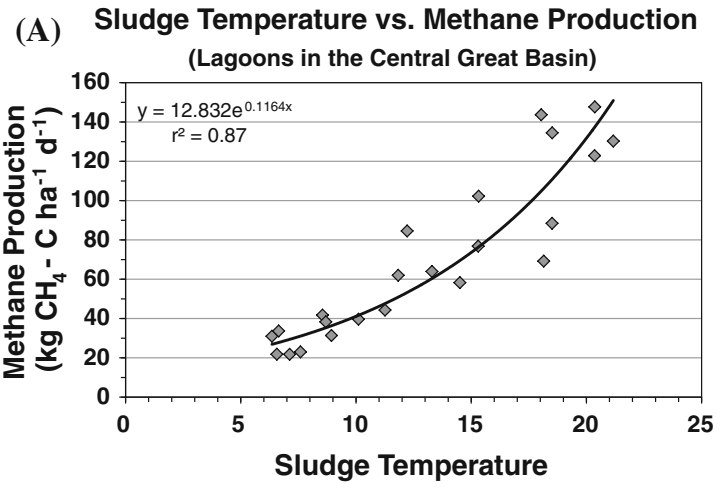

(B) Methane Production vs. Air Temperature

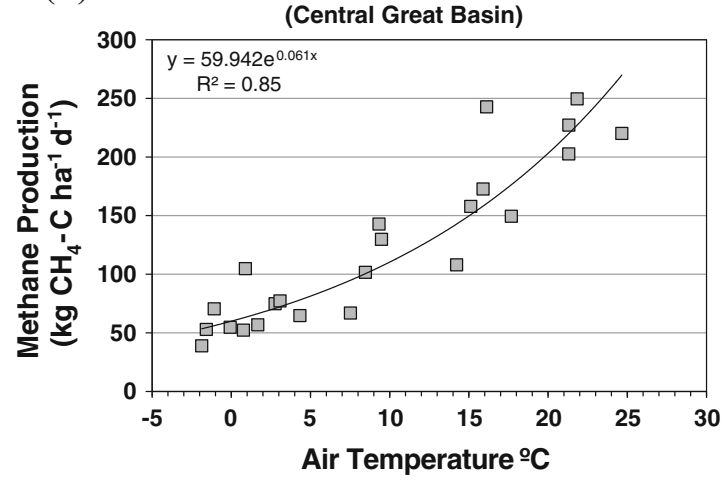

Fig. 3 a Average monthly methane production (of three farms) in relation to the sludge temperature at the bottom of the lagoons (where most of the decomposition occurs) over 2 years in the Central Great Basin (CGB). b Average monthly methane production (of three farms) in relation to the air temperature over 2 years in the CGB

oxygen $\left(\mathrm{O}_{2}\right)$ concentrations (mean of about $0.1 \%$ dissolved $\mathrm{O}_{2}$ across all the primary lagoons) can barely support autotrophic nitrification even under otherwise optimal conditions. We did not find $\mathrm{NO}_{2}{ }^{-}$, an intermediate step in biological nitrification/denitrification, in any of the primary lagoons. Zhang (2003) in studies of an anaerobic sludge reactor also found almost all nitrite removed (97-100 \%) with gas contents of 89,8 , and $3 \%$ of $\mathrm{N}_{2}, \mathrm{CH}_{4}$, and $\mathrm{CO}_{2}$, respectively. These and other anaerobic laboratory studies (Harper et al. 2001, unpublished data) showed similar conversion of solution $\mathrm{NH}_{4}{ }^{+}$to $\mathrm{N}_{2}$ gas. Studies of swine lagoons by Hunt et al. (2010) found similar conclusions to Harper et al. $(2000,2004)$ finding little $\mathrm{N}_{2} \mathrm{O}$ (produced from incomplete denitrification) being part of the system $\mathrm{N}$ balance. They also found there was a lack of sufficient denitrification enzyme activity (DEA) within the wastewater to support large $\mathrm{N}_{2}$ losses via classical nitrification and denitrification.

There are other possible microbial processes to explain the $\mathrm{N}_{2}$ production (Thamdrump 2012). Like classical denitrification and the anaerobic ammonia oxidation bacterial process (ANAMMOX), the full extent of conversion of $\mathrm{NH}_{4}^{+}$to $\mathrm{N}_{2}$ remains unclear (Ettwig et al. 2009). Kartal et al. (2011) has recently presented strong evidence to explain the ANAMMOX mechanism for conversion of $\mathrm{NH}_{4}{ }^{+}$to $\mathrm{N}_{2}$ production; meanwhile, in this paper we demonstrate that the simple conversion of $\mathrm{NH}_{4}^{+}$to $\mathrm{N}_{2}$ is thermodynamically favorable later in the manuscript.

Harper et al. (2000) showed that as lagoon $\mathrm{NH}_{4}{ }^{+}$ increased, $\mathrm{NO}_{3}{ }^{-}$and dissolved $\mathrm{O}_{2}$ decreased, while $\mathrm{N}_{2}$ and $\mathrm{CH}_{4}$ emissions increased. Other studies have shown that when organic $\mathrm{C}$ is removed for biogas production, methanogenesis is reduced and the lagoon $\mathrm{NH}_{4}{ }^{+}$content is increased (Amon et al. 2005) and 
measured whole-farm $\mathrm{NH}_{3}$ emissions are increased (Harper et al. 2010). The above studies had treatments which reduce methanogenesis or lagoon $\mathrm{NH}_{4}{ }^{+}$concentration but the studies in this research compare emissions from normal animal management and manure processing systems. The three lagoons in which organic matter was removed for biogas production were included to provide an additional comparison for the effect of reducing decomposition and methanogenesis.

\section{Thermodynamic relationships}

The net effect of all these studies suggests that as methanogenesis is decreased, conversion of $\mathrm{NH}_{4}{ }^{+}$to $\mathrm{N}_{2}$ is decreased. We think the causal relationship between methanogenesis and $\mathrm{NH}_{4}{ }^{+}$to $\mathrm{N}_{2}$ conversion is thermodynamically favored, while competing with other $\mathrm{NH}_{4}{ }^{+}$oxidizing reactions. The following reactions are considered:

$$
\begin{aligned}
\mathrm{NH}_{4}^{+}(\mathrm{aq})+0.75 \mathrm{O}_{2}(\mathrm{~g}) \rightarrow & 0.5 \mathrm{~N}_{2}(\mathrm{~g})+\mathrm{H}^{+}(\mathrm{aq}) \\
& +1.5 \mathrm{H}_{2} \mathrm{O}(\mathrm{l}) \\
\mathrm{NH}_{4}^{+}(\mathrm{aq})+2 \mathrm{O}_{2}(\mathrm{~g}) \rightarrow & \mathrm{NO}_{3}^{-}(\mathrm{aq})+2 \mathrm{H}^{+}(\mathrm{aq}) \\
+ & \mathrm{H}_{2} \mathrm{O}(\mathrm{l}) \\
\mathrm{NH}_{4}^{+}(\mathrm{aq})+1.5 \mathrm{O}_{2}(\mathrm{~g}) \rightarrow & \mathrm{NO}_{2}^{-}(\mathrm{aq})+2 \mathrm{H}^{+}(\mathrm{aq}) \\
& +\mathrm{H}_{2} \mathrm{O}(\mathrm{l})
\end{aligned}
$$

Reaction (1) could represent either a chemical denitrification step, or a microbial process. Without more direct evidence no distinction can be made between a chemical and a microbial process. Hence, we simply refer to reaction (1) as a "conversion" without specifying its nature. Reaction (2), or nitrification, is discussed below. Reaction (3) is significant as no appreciable concentrations of $\mathrm{NO}_{2}{ }^{-}$were determined in any of the lagoons. The nitrite ion is key for the anaerobic oxidation of $\mathrm{NH}_{3}$ (ANAMMOX) as $\mathrm{NO}_{2}{ }^{-}$must be present [Eq. (4)]:

$$
\mathrm{NH}_{4}^{+}(\mathrm{aq})+\mathrm{NO}_{2}^{-}(\mathrm{aq}) \rightarrow \mathrm{N}_{2}(\mathrm{~g})+2 \mathrm{H}_{2} \mathrm{O}(\mathrm{l})
$$

The Gibbs free reaction energy $\Delta_{\mathrm{r}} \mathrm{G}$ of the three reactions was calculated under the following conditions: $\mathrm{NH}_{4}{ }^{+}$concentration $1500 \mathrm{mg} \mathrm{L}^{-1}, \mathrm{NO}_{3}^{-}-\mathrm{N}$ concentration $0.1 \mathrm{mg} \mathrm{l}^{-1}, \mathrm{NO}_{2}{ }^{-}-\mathrm{N}$ concentration $0.1 \mathrm{mg} \mathrm{L}^{-1}, \mathrm{pH}$ $8, \mathrm{~N}_{2}$ partial pressure $81 \mathrm{kPa}, \mathrm{O}_{2}$ partial pressure $0.1-10^{-15}$ bar. The calculation is similar to that of
Harper et al. (2004b) except that the speciation between $\mathrm{NH}_{3}$ and $\mathrm{NH}_{4}{ }^{+}$was not considered $\left(\mathrm{NH}_{4}{ }^{+}\right.$is the dominant species and its concentration does not influence the relative $\Delta_{\mathrm{r}} \mathrm{G}$ between the three reactions).

This relationship is illustrated in Fig. 4. A negative value of $\Delta_{\mathrm{r}} \mathrm{G}$ indicates that the reaction is thermodynamically favorable. It is clear that the formation of $\mathrm{NO}_{3}{ }^{-}$from $\mathrm{NH}_{4}{ }^{+}$is thermodynamically more favorable than $\mathrm{N}_{2}$ or $\mathrm{NO}_{2}{ }^{-}$formation at $\mathrm{O}_{2}$ partial pressures above $10^{-8}$ bar when other concentrations remain the same. At lower $\mathrm{O}_{2}$ partial pressures $\mathrm{N}_{2}$ formation is thermodynamically more favorable than the formation of $\mathrm{NO}_{3}{ }^{-}$and $\mathrm{NO}_{2}{ }^{-}$from $\mathrm{NH}_{4}{ }^{+}$. This might explain why $\mathrm{N}_{2}$ production and $\mathrm{CH}_{4}$ production are correlated. Methanogenesis is only possible at extremely low $\mathrm{O}_{2}$ concentrations, and under these conditions $\mathrm{N}_{2}$ production is thermodynamically more favorable than $\mathrm{NO}_{3}{ }^{-}$ production. This should not be interpreted as conclusive evidence, as both reactions are thermodynamically favorable in all conditions considered; and, other factors like kinetics play a role as well. The presence of an electron donor (organic material) removes oxygen to the point where $\mathrm{NO}_{3}{ }^{-}$production becomes thermodynamically less favorable than $\mathrm{N}_{2}$ production. Kinetically, nitrification has an estimated saturation constant of $0.5 \mathrm{mg} \mathrm{L}^{-1}$ according to the standard activated sludge model, ASM3 (Gujer et al. 1999). The ASM3 model predicts that nitrifiers cannot maintain their activity at oxygen concentrations below $0.026 \mathrm{mg} \mathrm{L}^{-1}$ $\left(6.3 \times 10^{-4}\right.$ bar $)$ under otherwise optimal conditions (i.e., in the absence of any other limiting factor).

The sensitivity of the thermodynamics of reactions (1) (2), and (3) to the variables that were kept constant in the above analysis was investigated. The sensitivity of $\Delta_{\mathrm{r}} \mathrm{G}$ to any of the reactants or products was determined to be less than $11.42 \mathrm{~kJ} \mathrm{~mol}^{-1}$ for any 100 -fold change in concentration (or $2 \mathrm{pH}$ units). It is concluded that the thermodynamics of $\mathrm{NH}_{4}{ }^{+}$oxidation is only slightly sensitive to $\mathrm{pH}$ and concentrations of $\mathrm{NO}_{3}{ }^{-}, \mathrm{NO}_{2}{ }^{-}, \mathrm{N}_{2}$, and $\mathrm{NH}_{4}{ }^{+}$, so a possible uncertainty of any of these variables will not invalidate the analysis.

\section{Comparison of system $\mathrm{N}$ emissions}

The relative $\mathrm{N}$ emissions (ratio of $\mathrm{N}$ emitted to feed $\mathrm{N}$ input) from the farms in a geographical area (in NC) are shown in Fig. 5 (volatile $\mathrm{NH}_{3}-\mathrm{N}$ from housing and lagoons, $\mathrm{NH}_{4}{ }^{+}-\mathrm{N}$ conversion to $\mathrm{N}_{2}$, protein- $\mathrm{N}$, and unknown-N). Measured $\mathrm{N}_{2}$ emissions were not 
consistent within farm types or across all farm locations. The smallest $\mathrm{N}_{2}$ flux occurred in a farm (FW \#3) which also had the highest estimated housing $\mathrm{NH}_{3}$ emissions. Inversely, the largest $\mathrm{N}_{2}$ flux was in a farm (FF) with the smallest housing $\mathrm{NH}_{3}$ emission losses [housing $\mathrm{NH}_{3}$ emissions were only slightly linearly correlated with $\mathrm{N}_{2}$ emissions across all farms, $\left.\mathrm{R}=0.63\left(\mathrm{R}^{2}=0.40, \mathrm{n}=6\right)\right]$. Although not conclusive, the inverse relationship suggests that increased $\mathrm{N}$ loss as $\mathrm{NH}_{3}$ will reduce $\mathrm{N}_{2}$ emissions.

Statistical models for gas emissions

The correlation of methanogenesis and $\mathrm{N}_{2}$ emissions $\left(\mathrm{R}^{2}=0.78\right)$ was quite good across the lagoons studied in NC leading us to consider if the relationship $(y=0.23 x)$ would be comparable across wide geographical regions of the U.S., as well as with management practices. Methane and $\mathrm{N}_{2}$ emissions were combined (Fig. 6) with the studies in the CGB and from a previous study in GA (Harper et al. 2000). The relationship between $\mathrm{CH}_{4}$ and $\mathrm{N}_{2}$ emissions were surprisingly similar changing the overall correlation only slightly, $\mathrm{R}^{2}=0.71$, and a linear relationship of $y=0.20 \mathrm{x}$, suggesting a near-universal relationship between methanogenesis and conversion of $\mathrm{NH}_{4}$ to $\mathrm{N}_{2}$ in highly anaerobic conditions (comparing $\mathrm{NC}$ results to all results). The correlation of fluxes was significant at the $2 \%$ level $(t=3.76)$. A linear relationship can be inferred from the data:

$F_{\mathrm{N}_{2}}=B F_{\mathrm{CH}_{4}}$

with $F_{i}$ the flux of compounds $i$ in $\mathrm{kg} \mathrm{ha}^{-1} \mathrm{~d}^{-1}$ and $B$ an empirical coefficient. Based on simple linear regression, the value of $B=0.20$ is found because of the similar compositions of gas from individual systems.

The $\mathrm{S}$ farms were not included in the relationship (see $\mathrm{X}$ data point) since the animal size and management, feed input, and manure and urine management were very different.

Gas emissions will vary with respect to farm management (feed input, animal weight, etc.) and climatic conditions. As such, it is difficult to directly compare emissions from different locations. Farm management factors most correlated (and data most likely available) are feed input and size of animal. The climatic

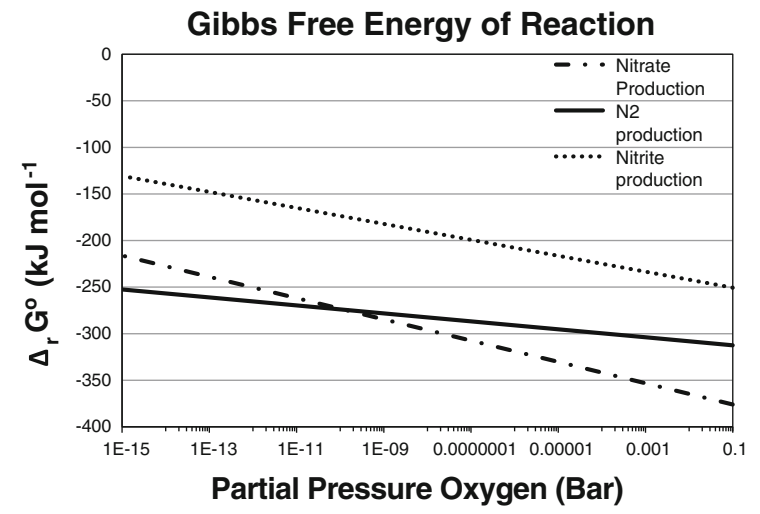

Fig. 4 Gibbs free energy of reaction for $\mathrm{N}_{2}$ production and $\mathrm{NO}_{3}{ }^{-}$production from $\mathrm{NH}_{4}{ }^{+}$versus $\mathrm{O}_{2}$ partial pressure $\left(\mathrm{NH}_{4}{ }^{+}\right.$ concentration $1,500 \mathrm{mg} \mathrm{L}^{-1}, \mathrm{NO}_{3}{ }^{-}$concentration $0.1 \mathrm{mg} \mathrm{L}^{-1}$, $\mathrm{pH} 8, \mathrm{~N}_{2}$ partial pressure $81 \mathrm{kPa}$ )

factor which most affects the biological decomposition of sludge is the temperature of the biological material in the lagoon anaerobic layer (i.e., sludge temperature, see Fig. 3a). Measurements were used from all the farm systems in the CGB to correct for temperature effects by correlating monthly air temperature with monthly gas emissions as discussed previously. The dependence upon feed input per surface area was estimated from NC data where there was no significant temperature difference between farms. Annual $\mathrm{CH}_{4}, \mathrm{~N}_{2}$, and $\mathrm{CO}_{2}$ emissions ( $\mathrm{kg}$ gas component $\mathrm{ha}^{-1} \mathrm{~d}^{-1}$ ) were estimated from lagoons by the following relationships:

$$
\begin{aligned}
\mathrm{CH}_{4}= & (0.023 \times \mathrm{FIS}-25) \\
& \times\left(0.039 \times \mathrm{T}_{\mathrm{a}}+0.26\right) \\
\mathrm{N}_{2}= & (0.0039 \times \mathrm{FIS}+1.3) \\
& \times\left(0.033 \times \mathrm{T}_{\mathrm{a}}+0.41\right) \\
\mathrm{CO}_{2}= & (0.0027 \times \mathrm{FIS}-7.4) \\
& \times\left(0.040 \times \mathrm{T}_{\mathrm{a}}+0.24\right)
\end{aligned}
$$

where FIS is the annual average daily feed input per lagoon surface area $\left(\mathrm{kg}\right.$ feed $\left.\mathrm{d}^{-1} \mathrm{ha}^{-1}\right)$ and $\mathrm{T}_{\mathrm{a}}$ is the average annual air temperature $\left({ }^{\circ} \mathrm{C}\right)$ at the site. Temperature corrections were standardized to the average annual air temperature in the NC studies $\left(18.85{ }^{\circ} \mathrm{C}\right)$. When these relationships were used to estimate $\mathrm{CGB}$ gas emissions, estimated $\mathrm{CH}_{4}$ emissions were $74 \pm 24 \%$ high, $\mathrm{CO}_{2}$ emissions were $58 \pm 13 \%$ low, and $\mathrm{N}_{2}$ emissions were $49 \pm 42 \%$ high compared to measured emissions. 


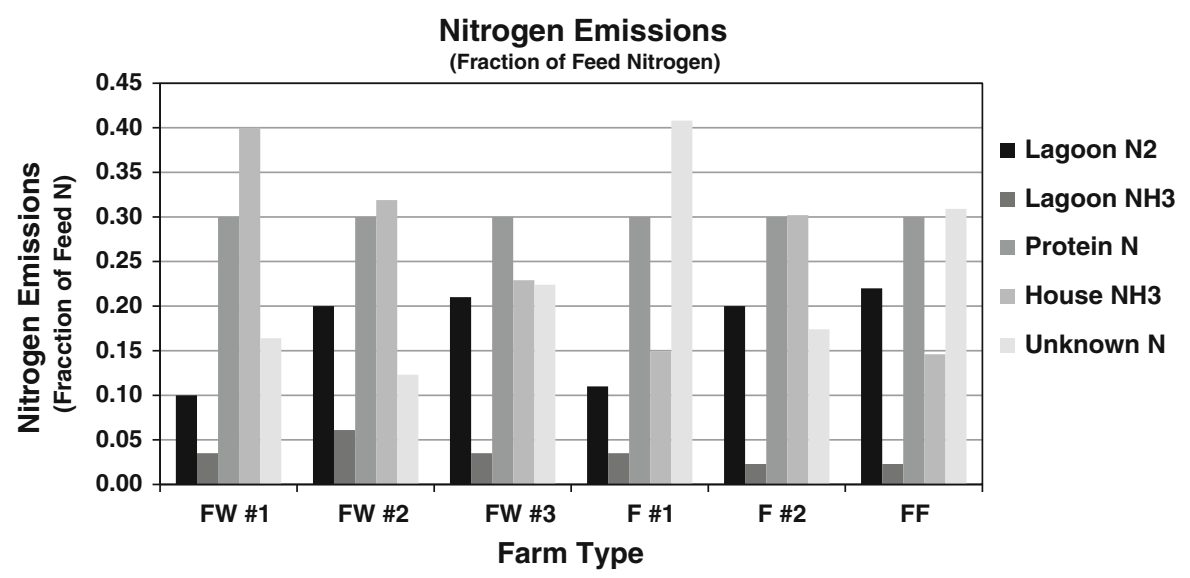

Fig. 5 Comparison of $\mathrm{N}$ emissions from farms due to housing $\mathrm{NH}_{3}$ losses, lagoon $\mathrm{NH}_{3}$ and $\mathrm{N}_{2}$ losses, and protein $\mathrm{N}$ removal from the farms ( $F$ finisher, $F F$ farrow to finisher, and $F W$ farrow to wean)

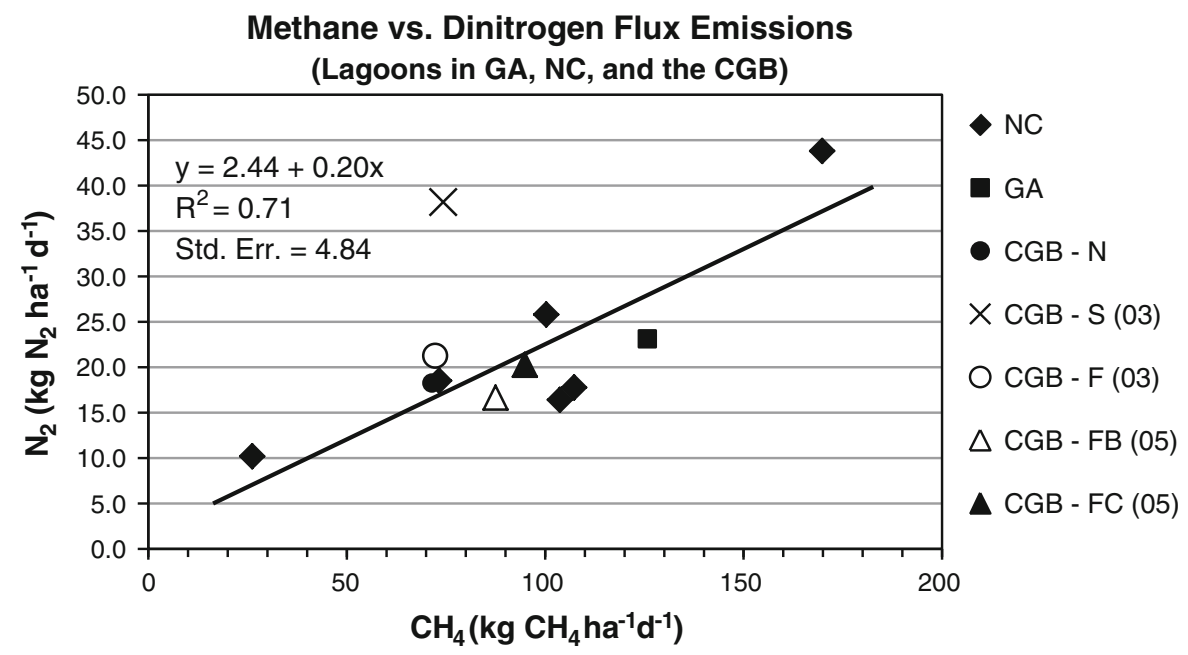

Fig. 6 Average annual dinitrogen production due to anaerobic decomposition in relation to methane production at six farms in North Carolina, 15 in the Central Great Basin (CGB, all data points from the CGB are the average of three identical farms), and one in Georgia (from Harper et al. 2000). The two data

Using information on the variables measured, we analyzed the data to determine the variables most related (and possibly causal), not already mentioned, to the conversion of $\mathrm{NH}_{4}{ }^{+}$to $\mathrm{N}_{2}$ for the studies in $\mathrm{NC}$. The amount of feed per average animal weight (and $\mathrm{C}$ input) had the highest correlation with $\mathrm{N}_{2}$ emissions $\left(\mathrm{R}^{2}=0.87\right)$. This is not surprising as feed per animal correlates highly with $\mathrm{C}$ and $\mathrm{N}$ lagoon input (and consequent increased methanogenesis), along with points from $\mathrm{CGB}-\mathrm{F}(05)$ are from Weaver et al. 2012. The Sow farm in the CGB was not used in the relationship since the animal and waste management systems were very different (see $\mathrm{X}$ data point)

$\mathrm{NH}_{4}$ conversion to $\mathrm{N}_{2}$, across studies over three states (Fig. 6).

\section{Conclusions}

In summary, gas emissions were measured in six anaerobic, manure-processing swine lagoons across $\mathrm{NC}, 15$ in the CGB, and one in GA. Conversion of 
$\mathrm{NH}_{4}{ }^{+}$to $\mathrm{N}_{2}$ was observed in all lagoons and a correlation was found between methanogenesis $\left(\mathrm{CH}_{4}\right.$ emissions) and conversion of ammoniacal $\mathrm{N}$ to benign $\mathrm{N}_{2}$ gas. Anaerobic digestion not only decomposes organic $\mathrm{C}$ to $\mathrm{CH}_{4}$, but also organic $\mathrm{N}$ to $\mathrm{NH}_{4}$ conceptually leading to an increase in $\mathrm{NH}_{4}$ concentration and, as a consequence, a potential increase in $\mathrm{NH}_{3}$ emissions. However, we find in these studies that a reduction of $\mathrm{C}$ causes an increase in $\mathrm{NH}_{3}$ emissions, rather than a decrease, since $\mathrm{NH}_{4}$ is not converted to $\mathrm{N}_{2}$. Dinitrogen emissions were seen to linearly increase with methanogenesis $\left(\mathrm{CH}_{4}\right.$ production), further explaining why removal of organic material from lagoons for biogas production would increase $\mathrm{NH}_{3}$ emissions from lagoons, a phenomenon which has been seen in other studies (Harper et al. 2010; Weaver et al. 2012). A causal effect for the relationship between methanogenesis and the potential conversion of $\mathrm{NH}_{4}{ }^{+}$to $\mathrm{N}_{2}$ is explained based on thermodynamics. Dinitrogen emissions can be estimated across all regions utilizing $\mathrm{CH}_{4}$ emissions (if available). The highest correlation between normally-obtained management variables and $\mathrm{N}_{2}$ emissions was input-feed per animalweight which provides the organic $\mathrm{C}$ for methanogenesis. Simple statistical regression models including average annual feed input and annual average air temperature were developed which explained most of the $\mathrm{N}_{2}$ emissions variability and had an acceptable error when tested against other lagoons. These studies provide the capability to estimate farm lagoon $\mathrm{CH}_{4}, \mathrm{CO}_{2}$ and $\mathrm{N}_{2}$ emissions from normally-available farm input and local climate data. Further investigations into the mechanisms of $\mathrm{NH}_{4}{ }^{+}$to $\mathrm{N}_{2}$ conversion and into the variability of $\mathrm{CH}_{4}$ emissions are needed.

Acknowledgments The authors wish to express their appreciation to the project technical assistants, M.F. Thornton, J. Scarbrough, C. Butler, P. Caddis, L. Mathis, and J. Merritt for their efforts in these studies and to the numerous undergraduate students from SUU for their assistance. Gratitude is expressed to R.R. Sharpe (USDA, ret.) for his support in these studies and to P. Rochette and T. Clough for manuscript reviews. A special thanks is extended to the Global Climate Change Program, USDA-ARS; the North Carolina Pork Council; the Utah Pork Council; Smithfield Co.; and to the host swine producers who helped make these studies possible.

Open Access This article is distributed under the terms of the Creative Commons Attribution License which permits any use, distribution, and reproduction in any medium, provided the original author(s) and the source are credited.

\section{References}

Amon B, Kryvoruchko V, Amon T, Boxberger J (2005) Effects of covering dairy cow slurry during storage on $\mathrm{CH}_{4}, \mathrm{NH}_{3}$, $\mathrm{N}_{2} \mathrm{O}$ emissions. Landtechnik 60:216-217

Aneja VP, Chauhan JP, Walker JT (2000) Characterization of atmospheric ammonia emissions from swine waste storage and treatment lagoons. J Geophys Res 105:11535-11545

Blunden J, Aneja VP (2008) Characterizing ammonia and hydrogen sulfide emissions from a swine waste treatment lagoon in North Carolina. Atmos Environ 42:3277-3290

Cohen AJ, Anderson HR, Ostro B, Pandey KD, Krzyzanowski M, Künzli N, Gutschmidt K, Pope A, Romieu I, Samet JM, Smith K (2005) The global burden of disease due to outdoor air pollution. J Toxicol Environ Health 68:1301-1307

De Visscher A, Harper LA, Westerman PW, Sharpe RR, Van Cleemput O (2002) Ammonia emissions from anaerobic swine lagoons: model development. J Appl Meteorol 41:426-433

DeSutter TM, Ham JM (2005) Lagoon-biogas emissions and carbon balance estimates of a swine production facility. J Environ Qual 34:198-206

Doorn MRJ, Natschke DF, Meeuwissen PC (2002a) Review of emission factors and methodologies to estimate ammonia emissions from animal waste handling. U.S. Environmental Agency Rept. EPA-600/R-02-017, April, 2002. U.S. Environmental Protection Agency, Washington, DC

Doorn MRJ, Natschke DF, Thorneloe SA, Southerland J (2002b) Development of an emission factor for ammonia emissions from US swine farms based on field tests and application of a mass balance method. Atmos Environ 36:5619-5625

Ettwig KF, Van Alen T, Van De Pas-Schoonen KT, Jetten MSM, Strous M (2009) Enrichment and molecular detection of denitrifying methanotrophic bacteria of the NC10 phylum. Appl Environ Microbiol 75:3656-3662

Gujer W, Henze M, Mino T, van Loosdrecht M (1999) Activated sludge model no. 3. Water Sci Technol 39:183-193

Harper LA (2005) Ammonia: Measurement Issues. In: J.L. Hatfield and J.M. Baker. (eds.) Micrometeorological Measurements in Agricultural Systems. Agron Monogr 47, ASA, CSSA, and SSSA, Madison WI p. 345-379

Harper LA, Sharpe RR (1998) Ammonia emissions from swine waste lagoons in the Southeastern U.S. Coastal Plains; Final Grant report to Division of Air Quality, North Carolina Department of Environment and Natural Resources, Raleigh, NC, USDA-ARS Agreement No. 58-6612-7 M022, December 1998. USDA-ARS, Watkinsville, GA, 1998

Harper LA, Sharpe RR, Parkin TB (2000) Gaseous nitrogen emissions from anaerobic swine lagoons: ammonia, nitrous oxide, and dinitrogen gas. J Environ Qual 29:1356-1365

Harper LA, Sharpe RR, Simmons JD (2004a) Ammonia emissions from swine houses in the southeastern United States. J Environ Qual 33:449-457

Harper LA, Sharpe RR, Parkin TB, De Visscher A, Van Cleemput O, Byers M (2004b) Nitrogen cycling in swine production systems: ammonia, nitrous oxide, and dinitrogen gas emissions. J Environ Qual 33:1189-1201 
Harper LA, Weaver KH, Dotson RA (2006) Ammonia emissions from swine waste lagoons in the Utah Great Basin. J Environ Qual 35:224-230

Harper LA, Flesch TK, Weaver KH, Wilson JD (2010) The effect of biofuel production on swine farm ammonia and methane emissions. J Environ Qual 39:1984-1992

Harper LA, Denmead OT, Flesch TK (2011) Micrometeorological techniques for measurement of greenhouse gas emissions from ruminant animal production. Anim Feed Sci Tech 166(167):227-239

Hatfield JC, Brumm MC, and Melvin SW (1993) Swine manure management. In: Agricultural Utilization of Municipal, Animal, and Industrial Waste, USDA-ARS, Washington, DC, 1993 p. 40-57

Hunt PG, Matheny TA, Ro KS, Vanetti MB, and Ducey TF (2010) Denitrification in anaerobic lagoons used to treat swine wastewater. J Environ Qual (published online, doi:10.2134/jeq2009.0385)

Kartal B, Maalcke WJ, de Almelda NM, Cirpus I, Gloerich J, Geerts W, Op den Camp HJM, Harhangt HR, JanssenMegens EM, Francoijs K, Stunnenberg HG, Keltjens JT, Jetten MSM, Strous M (2011) Molecular Mechanism of anaerobic oxidation. Nature 479:127-130

Pope CA III, Burnett RT, Thun MJ, Calle EE, Krewski D, Ito K, Thurston GD (2002) Lung cancer, cardiopulmonary mortality, and long-term exposure to fine particulate air pollution. J Am Med Assoc 287:1132-1141

Rochette P, Gregorich EG, Desjardins RL (1992) Comparison of static and dynamic closed chambers for measurement of soil respiration under field conditions. Can J Soil Sci 72:605-609

Shah SB, Westerman PW, Arogo J (2006) Measuring ammonia concentrations and emissions from agricultural and liquid surfaces: a review. J Air Waste Manage Assoc 56:945-960

Sharpe RR, Harper LA, Simmons JD (2001) Methane emissions from swine houses in North Carolina. Chemosphere-Global Change Sc. 3:1-6

Thamdrump B (2012) New pathways and processes in the global nitrogen cycle. Ann Rev Ecol Evol Syst 43:407-428

USEPA (2004) National Emission Inventory-Ammonia Emissions from Animal Husbandry Operations Draft Report, January 30, 2004. Report found at http//www.epa.gov/ttn/ chief/ap42/ch09

Van Cleemput O (1972) Het Denitrifikatieproces in De Bodem. (The denitrification Process in Soil). Ph.D. Thesis, Faculty of Agricultural and Applied Biological Sciences, University of Ghent, Ghent, Belgium, 1972. (in Flemish)

Van Cleemput O (1997) Subsoils: Chemical and biological denitrification, $\mathrm{N}_{2} \mathrm{O}$ and emissions. Proc. Intern. Workshop on dissipation of $\mathrm{N}$ from the human $\mathrm{N}$-Cycle and its role in present and future $\mathrm{N}_{2} \mathrm{O}$ emissions to the atmosphere. Agr Univ. Of Norway, Oslo. May 22-25, 1997. (No page numbers)

Weaver KH, Harper LA, Brown SM (2012) Effects on carbon and nitrogen emissions due to swine manure removal for biofuel production. J Environ Qual 41:1371-1382 